\title{
The Impact of Including Immigrants without Permanent Residence Status in the Public Health Insurance System in the Czech Republic
}

\author{
Jana Tepperová, Hana Zídková ${ }^{1}$
}

\begin{abstract}
Whether an individual can or cannot participate in the Czech public health insurance system depends on several characteristics, one of which is whether he/she has permanent residence status in the Czech Republic, and a second whether he/she is employed. This means that those without permanent residence status, including selfemployed migrants from third countries, their dependent relatives, and the dependent relatives of third country employees in the Czech Republic, cannot participate in the public health insurance system. Some argue that such migrants should be included in the system, since commercial health insurance is disadvantageous and the contributions they would pay into the public health insurance system would increase the public health insurance agencies' income. We estimate the value of the contributions to public health insurance that would be paid by third country self-employed and non-working immigrants, if they were insured based on data from 2011 to 2013, and compare this to the assumed costs of their medical care. To calculate the contributions for self-employed migrants we use data on the distribution of the tax base for self-employed persons from personal income tax returns. Our estimation results in an overall negative balance of 22 million CZK on the data for 2012 and 2013. In the current system this deficit would be covered by the state, which would pay contributions to the system for certain (state insured) persons amounting to 97 million $\mathrm{CZK}$; overall therefore the inclusion of these immigrants would result in a positive balance of 75 million CZK.
\end{abstract}

Key words: Migration; Public Health Insurance, Self-employment, Third countries, Dependent relatives.

JEL Classification: F22, J15, J61

Received: 19 September 2015 / Accepted: 29 January 2016 / Sent for Publication: 11 March 2016

\footnotetext{
${ }^{1}$ Both authors are assistant researchers at the Department of Public Finance, Faculty of Finance and Accounting, University of Economics, Prague. Contact address: nám. W. Churchilla 4, Prague 3. E-mail: jana.tepperova@vse.cz and hana.zidkova@vse.cz.
}

(C) 2016 by the authors; licensee Review of Economic Perspectives / Národohospodářský obzor, Masaryk University, Faculty of Economics and Administration, Brno, Czech Republic. This article is an open access article distributed under the terms and conditions of the Creative Commons Attribution 3.0 license, Attribution - Non Commercial - No Derivatives. 


\section{Introduction}

International migration and its impact on host countries' economies is one of the most frequently publicly discussed topics in developed European countries these days, and also one of the most controversial.

International migration has many forms from an economic viewpoint. Migrants from different (groups of) countries have different opportunities to enter host states, join the labour market there, participate in the social security system, and so on. Within the EU member states a clear distinction must be made between intra-EU migration and immigration from the so-called third countries.

However, migrants' experiences in the host country are not only affected by these territorial aspects, but also by their economic status - whether they are employees, selfemployed, dependent relatives, job-seekers - and other characteristics, such as their education level, age and so on. These can significantly influence the immigrant's overall fiscal position in the host country.

It is extremely important for immigrants not to lose their health coverage when migrating. In the Czech Republic, valid health insurance (public or private) is a legal requirement for residence.

According to the Czech national legislation (Art. 2 Act no. 48/1997 Coll., on public health insurance, Czech Republic, 1997), a person is required to participate in the public health insurance system if they have permanent residence in the Czech Republic or are employed by a Czech employer (meaning a company registered in the Czech Republic). Non-EU national can apply for permanent residence after 5 years of continuous residence in the Czech Republic. There is no voluntary participation in the public health insurance system, therefore other persons are not entitled to participate.

Participats of public health insurance system choose from several insurance companies that provide public health insurance. Currently there is seven insurance companies in the Czech Republic.

Employees and self-employed who qualify to participate in the system are required to pay contributions, which are based on their income. There is a significant group of persons whose contributions to the public system are covered by state (so called ,state insured persons"). On behalf of state insured persons, the state physically transfer the contribution to insurance companies. Persons can qualify as state insured for example as dependend children, pensioners, women on maternity leave, parents receiving parenting benefits, persons receiving sickness benefits, and others. (Art. 7 Act no. 48/1997 Coll., on public health insurance, Czech Republic, 1997).

Persons without income from employment or self-employment that are not considered as state insured but qualify to participate due to their permanent residence, pay fixed contribution determined by the law.

All participants of public health insurance system have free access to broad range of healthcare. According to the information from Ministry of Health, approximately 85\% of health care is covered from health insurance, as direct participation of the participants does not exceed 15\% (Ministry of Health of the Czech Republic, 2016). 
Immigrants from the EU/EEA countries and from Switzerland are covered by Regulation (EC) 883/2004 on coordination of social security and are thus also part of the public health insurance system, regardless of their residence status, if not insured in their home country. Besides Regulation (EC) 883/2004, the Czech Republic also has bilateral agreements on social security and health insurance coverage with Turkey, Israel and the countries of former Yugoslavia. The Czech Republic has also signed specific agreements with Yemen and Cuba on health care for temporary immigrants from these countries (Ministry of Health of the Czech Republic, 2015). Other bilateral agreements on social security concluded by the Czech Republic do not cover health insurance, although they are relevant to other aspects of social security, such as pension and sickness insurance (Ministry of Labour and Social Affairs, 2015).

Immigrants from third countries with whom the Czech Republic does not have a specific agreement find that their situation as regards public health insurance in the Czech Republic differs according to their employment status, i.e. whether they are selfemployed, employed or dependent relatives. Special treatment applies to asylumseekers, who are considered to have permanent residence status by law and thus are covered by public health insurance.

Self-employed immigrants from third countries who do not have permanent residence status are not within the scope of the public health insurance system, according to Czech national legislation; they do not contribute to the health care system through obligatory contributions, and they are not entitled to public health care coverage.

On the other hand, immigrants from third countries who are employed, whether or not they have permanent residence status, are within the scope of the public health insurance system for the duration of their employment. They pay contributions to the health care system and receive public health care coverage.

Dependent relatives (e.g. children) of immigrants from third countries who do not have permanent residence status are not within the scope of the public health insurance system, if they do not have permanent residence status themselves; this is the case regardless of whether the immigrant they are dependent on is employed (and therefore covered by the public health insurance system) or not. This can cause existential problems for families, as newborn babies often need specialised and highly expensive health care, which is not necessarily covered by commercial health insurance.

For those who are not allowed to participate in the public system, these migrants have to be covered by commercial health insurance, which is often more expensive and covers a lower level of health care than the public health insurance.

Hnilicová and Dobiášová (2011) find that guaranteeing legal entitlement to health care to all immigrants is a problematic issue within Czech health policy, since not all nonEU immigrants are entitled to join the public health insurance system. Dzúrová et al. (2014) suggest that the exclusion of immigrants from the public health insurance system may not be the only problem; they find evidence among immigrants from the Ukraine and Vietnam in the Czech Republic that even those immigrants who are eligible to participate in the public health insurance system either do not enter the system or are covered by both public and private insurance at once, mostly due to lack of awareness; thus it is clear that there is some inequality in access to the health insurance system. 
Within this paper we concentrate on the issue of health insurance for self-employed legal immigrants and their dependent relatives, as well as the dependent relatives of foreign employees from third countries who do not have permanent residence status in the Czech Republic. Their position is specific, as the EU regulations (and bilateral treaties) on social security coordination do not ensure their coverage within the public health insurance system, as it does for self-employed migrants from the EU states; their health coverage is not secured within Czech national legislation (as it is for third country nationals who are temporarily resident and employed in Czech companies).

The inclusion of temporarily resident self-employed migrants from third countries in the public health insurance system is quite a controversial issue in Czech public administration (Sdružení Občan, 2015). Some have argued that expenditure on providing health care for such migrants would exceed the contributions they would pay, pointing out potential problems with collecting contributions, and their potential misuse of the system (Kareš, 2015). Others believe that the revenue from contributions paid by selfemployed migrants would exceed expenditure on their health care, as they are attractive for the system due to their age distribution and health condition; thus their inclusion would be fair and appropriate (Čižinský, 2015). It is fairly difficult to provide a relevant estimate of the impact of including these migrants in the Czech public health insurance system, as it is not obvious how many immigrants are concerned, nor what their financial position is, since they are self-employed. Estimations of the number of legal migrants covered by commercial insurance are a helpful starting point, and were provided for example by Hnilicová et al. (2012) on data from 2012 and by Trbola and Rákoczyová (2010) on data from 2008; both these publications estimated that there were nearly 100,000 thousand such migrants in the Czech Republic. Most self-employed thirdcountry migrants living in the Czech Republic come from Vietnam, Ukraine, Russia and the USA (Ministry of Interior of the CR, 2014, p 11).

This analysis does not cover refugees, who have a distinct position within the public health insurance system. However, the current refugee situation in Europe (e.g. BBC, 2015) could indirectly influence decisions made regarding the other legal immigrants' participation in social security systems, including public health insurance system, since solving the current immigration 'crisis' will require significant costs in general.

This paper follows from discussions based on two conference papers by Tepperová and Zídková (2015a, 2015b). We build upon the methodology used within those conference papers and specify the relevant group of self-employed migrants more precisely, using additional data to provide more accurate results.

The aim of this paper is to provide a prediction of the economic impact of including temporarily resident self-employed migrants, their dependent relatives, and the dependent relatives of temporarily resident employees from third countries in the public health insurance system. We calculate the theoretical contributions self-employed immigrants from third countries would pay, if they were included in the system. Since temporarily resident self-employed migrants are not the only group of migrants from the third countries that are not currently covered by the Czech public health insurance system, we also aim to calculate the theoretical contributions for their dependent family members, who would be state-insured, as well as other persons without taxable income. Further we use figures on health care expenditure as published by the Czech Statistical Office (further 
"CSO") in CSO, 2013 to evaluate the effectiveness of including self-employed migrants and their dependent relatives in the public health insurance system. We summarize the results of our analysis, which is based on 2013 data, because more current data were not available to us. We compare these results with our previous research on data from 2011 and 2012 (Tepperová, Zídková, 2015a, 2015b).

\section{Data and methodology}

To calculate the impact of including currently excluded groups of third country migrants in the public health insurance system, it is necessary to:

- identify the relevant group(s) of immigrants to be incorporated into the system;

- calculate the potential income generated from their participation in the system, and

- estimate the costs incurred by the system as a result of those newly included groups

In this paper, we cover all three of these steps in order to calculate the potential impact of integrating all migrants from third countries who do not have permanent residence status into the Czech public health insurance system. We use data on the number of migrants from reports on migration issued by the Ministry of the Interior, as well as data from the General Financial Directorate on the distribution of the self-employed tax base and from the Czech Statistical Office on medical expenses. All these data are further specified in the later sections of this paper. All data used are for the year 2013, with the exception of annual medical expenses per person and the age composition of the immigrants, for which data for 2012 are used, as newer data were not available. However, we assume that this type of data does not change significantly from year to year.

After specifying the relevant group of immigrants to be included, we calculate that group's potential contributions to the health insurance system, and compare this with the annual medical expenses that would be expected for the group. This simple comparison enables us to evaluate the group's inclusion based on the available economic variables. Economically, including these immigrants within the system would be appropriate if the potential contributions they would pay would exceed the system's assumed costs in the form of their medical care. However, it is important not to count any contributions for particular sub-groups of these immigrants (namely dependent children and retired people), since under the current rules of the health insurance system, these individuals' contributions would be paid by the state; thus, although they would bring money into the health insurance system, they would place a burden (of equal value) on the state budget. Furthermore, we are not reasonably able to include variables within our estimation that would express issues such as the immigrants' potential misuse of the system, or the potential decline in the immigrants' health in the future.

Our methodological strategy can be formalized in the following formulas:

$$
P C>T C
$$

Where PC is Potential contributions to health insurance system and TC is Total costs.

This can be further specified in Formula 2: 


$$
\sum_{i=1}^{k} \frac{n_{i} \times A T B_{i}}{2} \times 0,135+P P \times(P P C \times 12)>M C
$$

Where MC stands for Medical care costs; PP is Estimated number of persons without taxable income (but not state-insured), i.e. so-called private payers; $n_{i}$ is Estimated number of self-employed immigrants in the ith range of the tax base; $A T B_{i}$ is Average tax base in the ith range of tax base (if the average tax base is lower than the minimum assessment base, than the ATB equals the minimum assessment base); PPC is Private payers' contribution per month (in 2013, this minimal contribution was 1,080 CZK per month)

\section{Specification of the group of migrants to be included}

We define the group of immigrants to be 'newly' included within the system, for the purpose of our estimation, as immigrants with a long-term visa but temporary residence status who are self-employed in the Czech Republic, and their dependent relatives with temporary residence status, especially children and spouses. We also include temporarily resident dependent relatives of immigrants who are employed in the Czech Republic. Employees from third countries are themselves insured by the public health insurance system, but their dependent family members are not.

Within this group, we consider only those immigrants from non-EU/EEA countries that are not covered by any Regulations or Bilateral treaties covering health insurance, as described in detail in section 2.

For the purposes of our calculation, we distinguish between self-employed and nonworking immigrants (i.e. dependent relatives). The reason for this is that the potential contributions to the public health insurance system are calculated differently for each of these groups. Self-employed immigrants would contribute to the system based on their earnings, whereas non-working persons would either have their contributions covered by the state (if they are dependent children or pensioners) or would pay fixed contributions themselves, if they are so-called persons without taxable income (Czech Health Insurance Act 48/1997 Coll.).

The number of immigrants who would newly qualify for health insurance if this group was included within the system is taken from data published by the Ministry of Interior in its "Report on Migration" (Ministry of the Interior of the Czech Republic, 2014). This report contains the following information relevant for our calculation:

(1) The total number of immigrants resident in the Czech Republic with permanent residence and temporary residence status, divided into EU and non-EU groups as indicated in Table 1 below: 
Table 1 Migrants from the third countries according to their visas as of the end of $\mathbf{2 0 1 3}$

\begin{tabular}{lr}
\hline Migrants from third countries with temporary residence status & 96712 \\
Migrants from the EU, EEA and Switzerland with temporary residence status & 105920 \\
Migrants with temporary residence status - total & 202632 \\
\hline Migrants from third countries with permanent residence status & 170436 \\
Migrants from the EU, EEA and Switzerland with permanent residence status & 68468 \\
Migrants with permanent residence status - total & 238904 \\
\hline All migrants - total & 441536 \\
\hline Migrants from third countries - total ( temporary and permanent residence status) & 267148 \\
Proportion of migrants from third countries with temporary residence status (96 712/ & 0.3620
\end{tabular}

Source: Data from Report on Migration, Ministry of the Interior of the Czech Republic (2014)

(2) The number of immigrants according to their economic activity (employed and selfemployed) but not divided into long term and permanent residence status as shown in Table 2 below:

Table 2 Migrants from third countries with temporary residence status according to their economic activity for 2013

\begin{tabular}{lcr}
\hline Employees from the EU, EEA and Switzerland & $(1)$ & 184513 \\
Employees from third countries & $(2)$ & 62451 \\
\hline Employed migrants - total & $(1)+(2)$ & 246964 \\
Self-employed from the EU, EEA and Switzerland & $(3)$ & 21766 \\
Self-employed from third countries & $(4)=(5)+(6)$ & 64121 \\
\hline Self -employed migrants - total & $(3)+(4)$ & 85887 \\
\hline Self-employed from third countries with a treaty & $(5)$ & 1613 \\
Self -employed from third countries without a treaty & $(6)$ & 62508 \\
\hline
\end{tabular}

Source: Data from Report on Migration, Ministry of the Interior of the Czech Republic (2014), own adjustments

(3) The total number of employed immigrants with temporary residence status who require employment permits. 
Table 3 Employed migrants from third countries with temporary residence status

Employees from third countries with temporary residence status (who require employment permits)

Source: Report on Migration, Ministry of the Interior of the Czech Republic (2014)

As we need the number of self-employed immigrants with temporary residence status for our calculation, we use the proportion of immigrants from third countries with temporary residence status on all immigrants from third countries, as calculated in Table 1 above.

The number of non-working immigrants (children, non-working spouses, retired persons, students, etc.) is deduced from the three pieces of information indicated above.

The calculation of the necessary figures is explained in Table 4 below.

Table 4 Self-employed and non-working migrants from third countries with temporary residence status

All self-employed from third countries (with permanent residence

status or long term visas)

64121

Proportion of immigrants from third countries with temporary residence status)

Self-employed from third countries with temporary residence status (estimated)

$(3)=(1) \times(2)$

All immigrants from third countries with temporary residence status (see Table 1)

Employees from third countries with temporary residence status (see Table 3)

23662

Non-working migrants from third countries

(6) $=(4)-(3)-(5)$ 49837

Source: Report on Migration, Ministry of the Interior of the Czech Republic (2014) and own calculation

When it comes to non-working immigrants, only those who are not covered by any treaty on social security should be considered for our estimation of their potential health insurance contributions. Therefore we must adjust the number of non-working immigrants calculated in Table 4 accordingly. As we do not have detailed information on the individual countries from which the non-working immigrants originate, we use the proportion of self-employed immigrants from non-treaty countries out of all selfemployed immigrants from third countries. The number of self-employed immigrants from non-treaty countries is estimated from item (6) in Table 2 using the proportion of immigrants long term visas out of immigrants as calculated in Table 4 (item 2). The number of non-working immigrants from non-treaty countries is thus calculated in Table 5 below. 
Table 5 Non-working immigrants with temporary residence status from third countries without treaties

\begin{tabular}{lcr}
\hline $\begin{array}{l}\text { Self-employed immigrants from third non-treaty countries with } \\
\text { temporary residence status (item } 6 \text { from Table } 2 \text { x item } 2 \text { from }\end{array}$ & (1) \\
$\begin{array}{l}\text { Table 4) } \\
\begin{array}{l}\text { Self-employed immigrants from third countries with temporary } \\
\text { residence status - item (3) from Table } 4\end{array}\end{array}$ & 22629 \\
\hline $\begin{array}{l}\text { Proportion of self-employed immigrants from third non-treaty } \\
\text { countries with temporary residence status }\end{array}$ & $(3)=(1) /(2)$ & 0.9748 \\
\hline $\begin{array}{l}\text { Non-working migrants from third countries - item } 6 \text { from Table } 4 \\
\text { Non-working immigrants from third non-treaty countries }\end{array}$ & $(4)$ & 49837 \\
\hline
\end{tabular}

Source: Data from Report on Migration, Ministry of the Interior of the Czech Republic (2014) and own calculation

Furthermore, we need to divide the group of immigrants according to their age. For the non-working immigrants (state insured persons and persons without taxable income) in the group, this will enable us to calculate their health insurance contributions, while it is important for the whole group as it affects the estimated medical costs associated with their inclusion in the public health insurance system.

The distribution of immigrants from third non-treaty countries into age groups is estimated based on the data for all immigrants with long term visas in the Migration Report for 2012 (Ministry of the Interior of the Czech Republic, 2013). In the Migration report for 2013 (Ministry of the Interior of the Czech Republic, 2014), data on immigrants are not divided according to their age. The age composition of all immigrants (i.e. from EU and non-EU countries - unfortunately, the specific data for non-EU migrants were not available) in 2012 is shown in Table 6 below.

Table 6 All immigrants temporary residence status according to their age

\begin{tabular}{lcccccccc}
\hline Age group & $0-18$ & $19-25$ & $26-35$ & $36-45$ & $46-55$ & $56-65$ & $66+$ & Total \\
\hline $\begin{array}{l}\text { Number of } \\
\text { immigrants }\end{array}$ & 18632 & 28804 & 78201 & 49032 & 32948 & 12801 & 3768 & 224186 \\
$\begin{array}{l}\text { Relative } \\
\text { frequencies }\end{array}$ & 0.083 & 0.128 & 0.349 & 0.219 & 0.147 & 0.057 & 0.017 & 1.000 \\
\hline
\end{tabular}

Source: Report on Migration, Ministry of Interior of the Czech Republic (2013) and own calculation

\section{Calculation of contributions}

To calculate the assumed contributions that would be made by these immigrants if they joined the public health insurance system, we use information on the tax base from selfemployment (section 7 of the Income Taxes Act, further "the ITA", Czech Republic, 1992), which is declared by self-employed individuals in the personal income tax returns they submit to the tax authorities, in particular the data on line 37 of the tax return 
(tax base from self-employment). We use data from the ADIS system kept by the Ministry of Finance (further only "MF”), as used in Vančurová, Mazouch, and Klazar (2015).

So far, we have not been able sort this primary data by the taxpayers' nationality, which would be optimal for our analysis. Therefore, we instead assume that the tax base distribution in the group of self-employed immigrants we are considering is the same as in the whole population of self-employed persons in the Czech Republic. Based on this premise, we estimate the tax base distribution for the group in question using the number of immigrants in the group and the distribution of tax base from self-employment as given in the summarized data available from the MF.

Taking into account comments we received on our previous research (Tepperová, Zídková, 2015a, 2015b), we use data not only on individuals' tax base from selfemployment but also take into account the fact that some self-employed individuals have an additional minor income from employment (up to 100,000 CZK), but are not likely to be insured from that employment (because it is too minor), as shown in Figure 1 below. This enables us to achieve a more realistic calculation of the tax base distribution for self-employed immigrants from third countries.

Figure 1 Distribution of the tax base from self-employment for self-employed individuals (with concurrent income from employment up to $100,000 \mathrm{CZK}$ ) among the population of taxpayers in the Czech Republic

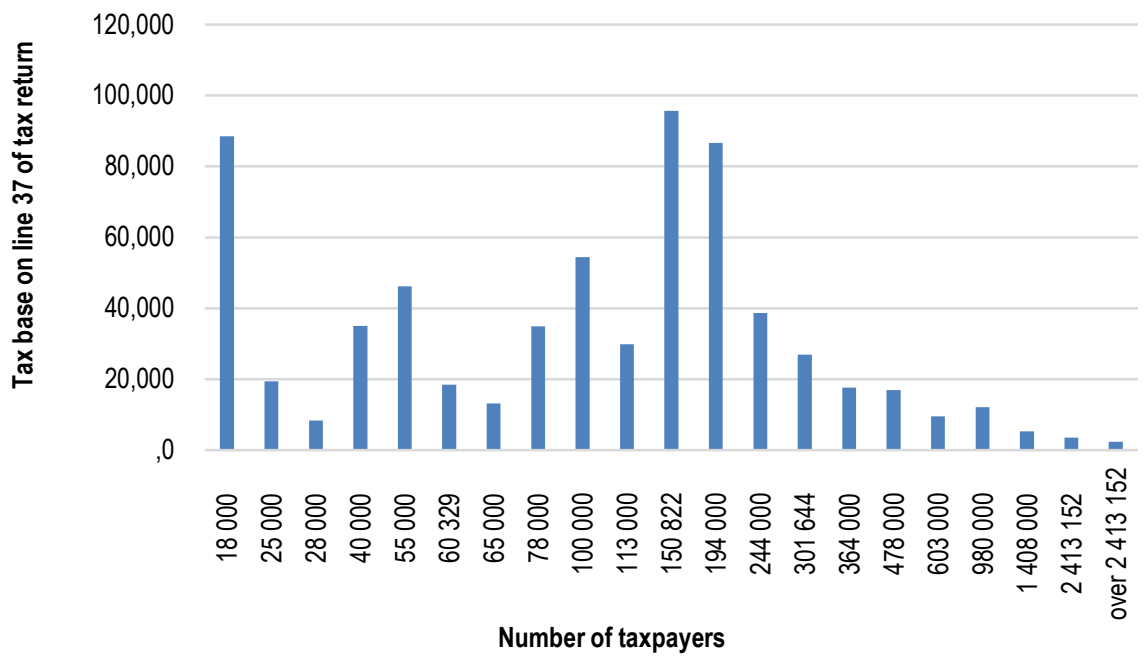

Source: data from Ministry of Finance, as used in Vančurová, Mazouch, and Klazar (2015)

The assessment base for the calculation of health insurance contributions for selfemployed taxpayers is $50 \%$ of the unadjusted tax base (total income less expenses incurred) declared according to section 7 of the ITA. This means that we can use the tax base declared by self-employed immigrants from non-treaty third countries (further only 
"self-employed immigrants") to calculate the contributions they would pay if they were incorporated into the public health insurance system.

To estimate their tax base from the distribution shown in Figure 1, we firstly apportion numbers of self-employed immigrants to each tax base range based on the relative frequencies found in the whole population of self-employed taxpayers. We then estimate the immigrants' total unadjusted tax base for each tax base range by multiplying the number of immigrants by the average unadjusted tax base (from the whole population). We calculate the base for the immigrants' health insurance contribution as $50 \%$ of the estimated tax base for each range (product of column 2 and 3 in Table 7; the calculation was carried out without any rounding the numbers in column 2 and 3 ).

The self-employed immigrants' potential contributions are then computed as the product of the estimated assessment base and the rate of $13.5 \%$. We take into account the minimum assessment base, which is applicable in cases where the average monthly health insurance contribution per immigrant computed from the total assessment base would be less than the minimum monthly health insurance contribution of $1,748 \mathrm{CZK}$. We do not use a maximum assessment base in our calculation, as this is not currently used by the health insurance system. Our contribution calculations are summarised in Table 7 below.

Table 7 Estimated annual health insurance contributions for self-employed immigrants from non-treaty third countries

\begin{tabular}{rrrrrr}
\hline $\begin{array}{c}\text { Intervals of self- } \\
\text { employed - tax } \\
\text { base according to } \\
\text { I. } 37\end{array}$ & $\begin{array}{c}\text { Estimated } \\
\text { number of } \\
\text { migrants }\end{array}$ & $\begin{array}{c}\text { Estimated } \\
\text { average tax } \\
\text { base per } \\
\text { taxpayer }\end{array}$ & $\begin{array}{c}\text { Estimated assessment } \\
\text { base for health insur- } \\
\text { ance contributions }\end{array}$ & $\begin{array}{c}\text { Monthly } \\
\text { contribution } \\
\text { per person }\end{array}$ & $\begin{array}{c}\text { Annual contribution } \\
\text { taking into account } \\
\text { the minimum as- } \\
\text { sessment base }\end{array}$ \\
\hline 18000 & 3014 & -76108 & -114689919 & 1748 & 63218988 \\
25000 & 662 & 21585 & 7147110 & 1748 & 13891040 \\
28000 & 285 & 26494 & 3778205 & 1748 & 5982502 \\
40000 & 1194 & 34125 & 20380023 & 1748 & 25054184 \\
55000 & 1575 & 47607 & 37498556 & 1748 & 33044194 \\
60329 & 628 & 57856 & 18167576 & 1748 & 13173511 \\
65000 & 451 & 62658 & 14140935 & 1748 & 9467947 \\
78000 & 1189 & 71537 & 42516803 & 1748 & 24933405 \\
100000 & 1856 & 88878 & 82490015 & 1748 & 38936647 \\
113000 & 1019 & 106428 & 54206606 & 1748 & 21367202 \\
150822 & 3260 & 133615 & 217806252 & 1748 & 68386051 \\
194000 & 2953 & 168687 & 249062999 & 1748 & 61941158 \\
244000 & 1319 & 216330 & 142697317 & 1748 & 27672735 \\
301644 & 919 & 270588 & 124357441 & 1748 & 19280366 \\
364000 & 603 & 330487 & 99622575 & 1859 & 13449048 \\
478000 & 577 & 412806 & 119120660 & 2322 & 16081289 \\
603000 & 327 & 534853 & 87433512 & 3009 & 11803524
\end{tabular}




\begin{tabular}{rrrrrr}
980000 & 412 & 758650 & 156340610 & 4267 & 21105982 \\
1408000 & 181 & 1165919 & 105446909 & 6558 & 14235333 \\
2413152 & 122 & 1774912 & 108457878 & 9984 & 14641814 \\
$2413152+$ & 81 & 6716041 & 272640409 & 37778 & 36806455 \\
\hline Total & 22629 & & 1848622472 & $\mathbf{5 5 4 4 7 3 3 7 3}$ \\
\hline
\end{tabular}

Source: data from Ministry of Finance of the Czech Republic, as used in Vančurová, Mazouch, and Klazar (2015), own calculation

For non-working immigrants from non-treaty third countries on long-term visas we calculated the contributions as follows. If these individuals have no taxable income, they would have contributed 1,080 CZK per month in 2013. If they qualified for their contributions to be paid by the state (children and pensioners) then in 2013 the state would have paid monthly contributions of $723 \mathrm{CZK}$ to their health insurance provider on their behalf.

Table 8 summarizes our estimation of the contributions that would be paid by selfemployed immigrants, immigrants without taxable income (e.g. spouses of selfemployed or employed immigrants) and on behalf of state-insured immigrants from non-treaty third countries, if they were included in the public health insurance system based on 2013 data.

The calculation uses estimates of the total numbers of non-working immigrants who would be state-insured (i.e. children, students up to 24 years of age and pensioners aged over 65) and of immigrants without taxable income (i.e. those aged between 24 and 65 years who are neither employed or self-employed). These estimates were calculated based on Table 5, which provides the total number of non-working immigrants, and Table 6, which contains the age distribution of all immigrants. We have assumed that non-working immigrants have the same age distribution as the immigrant population as a whole, as we did not have the data on age distribution based on the economic status of immigrants.

Table 8 Estimate of total health insurance contributions (in CZK) for immigrants from nontreaty third countries (self-employed and non-working).

\begin{tabular}{lcr}
\hline & Number of migrants & \multicolumn{1}{c}{ Total contributions } \\
\hline Self-employed & 22629 & 554473373 \\
State-insured (dependent relatives) & 11126 & 96524899 \\
Persons without taxable income & 37457 & 485449109 \\
\hline Total revenues & 1136447381 \\
\hline Total revenues without state contribu- & 1039922482 \\
\hline tions & & \\
Source: Ministry of Finance of the Czech Republic, Ministry of the Interior of the Czech Republic, \\
CSO described above, own calculation
\end{tabular}




\section{Calculation of costs}

In order to calculate the total expenses that would be incurred by the public health insurance system if our group of immigrants was to enter the system, we use the estimated composition of the group of immigrants from non-treaty third countries by age, as in Table 6 . We also consider the proportion of men and women in the group of immigrants as stated in the Migration Report (Ministry of the Interior, 2013). This was necessary because average medical expenses per person differ significantly based on gender as well as age. Data on average medical costs per person are taken from CSO (2013); no more recent data were available.

We calculate the total expenses that would potentially be incurred for the medical treatment of immigrants from non-treaty third countries, both per age group and in total. The results are summarized in Table 9 below:

Table 9 Medical costs associated with immigrants from non-treaty third countries for 2013

\begin{tabular}{lcrrrrrrr}
\hline Age group & \multicolumn{1}{c}{$0-18$} & \multicolumn{1}{c}{$19-25$} & \multicolumn{1}{c}{$26-35$} & \multicolumn{1}{c}{$36-45$} & \multicolumn{1}{c}{$46-55$} & $56-65$ & $66+$ & Total \\
\hline Migrants & 5918 & 9150 & 24840 & 15575 & 10466 & 4066 & 1197 & 71212 \\
Women & 2302 & 3559 & 9662 & 6058 & 4071 & 1582 & 466 & 27700 \\
Men & 3616 & 5591 & 15178 & 9517 & 6395 & 2485 & 731 & 43512 \\
$\begin{array}{l}\text { Exp. per } \\
\text { women }\end{array}$ & 11569 & 7887 & 9144 & 11533 & 17712 & 32141 & 58559 & \\
$\begin{array}{l}\text { Exp. per men } \\
\text { Exp. per age }\end{array}$ & 11459 & 11021 & 14656 & 15041 & 19789 & 27029 & 49316 & \\
$\begin{array}{l}\text { group in } \\
\text { thousands }\end{array}$ & 68074 & 89683 & 310789 & 213009 & 198648 & 117989 & 63329 & 1061520 \\
CZK & & & & & & & & \\
\hline
\end{tabular}

Source: CSO (2013), Ministry of the Interior of the Czech Republic (2013), own calculation

Comparison of results for 2011, 2012 and 2013

We compare our calculations for 2013 with previous calculations of the potential health insurance contributions the discussed immigrants would have paid for years 2011 and 2012, as reported in our previous research (Tepperová, Zídková, 2015a and 2015b); the results of this comparison are reported in Table 10.

Although we used slightly different data for the 2011 and 2012 calculation (in this paper, we used as a reference point the tax base of all self employed including those who had minor income from employment), the results are similar. The differences are most likely influenced by the changing number of immigrants rather than from the different data used for the self-employed tax base distribution in the Czech Republic. 
Table 10 Estimated health insurance contributions for self-employed and non-working immigrants from non-treaty third countries in the years $2011-2013$

\begin{tabular}{|c|c|c|c|}
\hline & \multicolumn{2}{|c|}{$\begin{array}{l}\text { Total contributions } \\
\text { (Number of migrants) }\end{array}$} & \multirow[b]{2}{*}{2013} \\
\hline & 2011 & 2012 & \\
\hline Self-employed & $\begin{array}{r}723134370 \\
(31,939)\end{array}$ & $\begin{array}{r}698630389 \\
(31,050)\end{array}$ & $\begin{array}{r}554473373 \\
(22,629)\end{array}$ \\
\hline State-insured & $\begin{array}{r}106635825 \\
(12,291)\end{array}$ & $\begin{array}{r}141163067 \\
(16,271)\end{array}$ & $\begin{array}{r}96524899 \\
(11,126)\end{array}$ \\
\hline Persons without taxable income & $\begin{array}{r}389985935 \\
(30,092) \\
\end{array}$ & $\begin{array}{r}709946199 \\
(54,780) \\
\end{array}$ & $\begin{array}{r}485449109 \\
(37,457) \\
\end{array}$ \\
\hline Total revenues & 1219756130 & 1549739654 & 1136447381 \\
\hline
\end{tabular}

\section{Conclusion}

Our calculation for 2013 reveals that the medical expenses that would probably be incurred if self-employed and non-working immigrants from non-treaty third countries were included in the public health insurance system would amount to 1,062 million CZK. Meanwhile, the contributions that these migrants would be required to pay into the system, not including contributions paid by the state, would amount to 1,040 million CZK. Thus, the resulting impact is negative to the tune of 22 million CZK. This negative balance represents the solidarity necessitated by the immigrants' inclusion in the system. In the current Czech public health insurance system, this negative balance would be covered from state budget through the contributions the state pays on behalf of so-called state insured persons (children, students up to age 24 and pensioners). As we have seen, the contributions the state would pay on behalf of immigrants in these categories would amount to 97 million CZK; in total, therefore, the inclusion of the group of immigrants we have considered in the public health insurance system would lead to a positive balance for the public health insurance system of 75 million CZK. But to achieve this positive economic impact would require Czech taxpayers' support for the contribution from the state budget, and it is not clear whether Czech taxpayers would approve such solidarity. In a press release in November 2015, the main Czech provider of commercial health insurance for immigrants presented a study by STEM/MARK, according to which $76.7 \%$ of Czech nationals are against the further inclusion of immigrants from third countries in the public health insurance system (VZP, 2015). According to the same source, this percentage had increased from the previous year, which is not surprising given sensitivity surrounding the current influx of immigrants to the EU countries, as it might be difficult for public to distinquish between the legal health care rights of asylum seekers and specific group of immigrants from third countries that stay in the Czech republic as self-employed and their dependent relatives.

We were not able to consider potential differences in tax compliance between selfemployed third-country migrants and self-employed natives or EU/treaty country migrants, as there are no data that could be used to reasonably judge tax compliance in these groups; the same applies to any difference in the real medical expenses the migrant group would incur compared with the currently insured population. 
Our data on the distribution of income from self-employment (see Table 7) shows that almost $90 \%$ of all self-employed non-treaty third country immigrants would pay contributions based on the minimum assessment base. This corresponds to approximately 20,000 immigrants in 2013. By contrast, Kulich (2014) provides a calculation of the potential revenue of the inclusion of foreigners in the public health insurance system, which assumes they would pay significantly higher contributions; he assumes revenue in the range 1.7 billion to 3.1 billion $\mathrm{CZK}$, depending on how many foreigners join the system. These vastly different results are partly because he works with a higher number of foreigners due to his different methodology. Second, we believe that he overestimates the assessment base for the calculation of the contributions, as he calculates based on an monthly income for the self-employed of 53,602 CZK. This is not in line with the data we used on the real tax base distribution among the self-employed.

The matters we have presented in this paper may lead to numerous discussions on the way the whole public health insurance system is organised, including whether there should be a higher minimum contribution, whether a minimum period of residence (probably in months) should be required before immigrants could participate in the system, and whether insurance provision for their dependent family members should be limited. The state insurance of immigrants' dependent family members might also be called into question, and proposals could be made for these individuals to contribute a minimum amount rather then be covered by the state, as such a policy would result in an overall positive balance for the Public health insurance system, based on our results.

Funding: This paper is one of the outputs of a research project at the Faculty of $\mathrm{Fi}$ nance and Accounting, University of Economics, Prague, which is carried out with the institutional support of the University of Economics in Prague, number IP 100040.

This paper is part of research project number F1/1/2016 "Public finance in the Czech Republic and the EU".

Disclosure statement: "No potential conflict of interest was reported by the author."

\section{References}

BBC (2015). As it happened: Migrant Crisis [online]. [cit. 18.9.2015] Available from http://www.bbc.com/news/live/world-europe-34289822

ČIŽINSKÝ, P. (2015). Proč začlenit cizince do veřejného zdravotního pojištění?. Záznam diskusního setkání na téma "Patří cizinci do veřejného zdravotního pojištění?", Sdružení Občan, Available from https://www.youtube.com/watch?v=2F1ZhEisJUI

CZECH STATISTICAL OFFICE (2012). Cizinci v České republice podle dat sčítání lidu [online]. [cit. 18.9 .2015$]$ Available from http://www.czso.cz/csu/2014edicniplan.nsf/publ/170222-14-n_2014 
CZECH STATISTICAL OFFICE (2013). Výsledky zdravotnických účtů ČR 2000 2012. Available from http://www.czso.cz/csu/2014edicniplan.nsf/publ/260005-14r_2014

CZECH REPUBLIC (1992). Zákon č. 586/1992 Sb., o daních z prřijmů, ve znění pozdějších předpisů.

CZECH REPUBLIC (1997). Zákon č. 48/1997 Sb., o veřejném zdravotním pojištění a o změně a doplnění některých souvisejících zákonů.

DZÚROVÁ, D., WINKLER, P., and DRBOHLAV, D. (2014). Immigrants' Access to Health Insurance: No Eyuality without Awareness. International Journal Of Environmental Research and Public Healths, 2014, 11, 7144-7153.

EUROPEAN PARLIAMENT AND THE COUNCIL (2004). Regulation (EC) No $883 / 2004$ on the coordination of social security systems. 29 April 2004 [online]. Available from lex.europa.eu/LexUriServ/LexUriServ.do?uri=CELEX:32004R0883:EN:NOT http://eur-

EUROPEAN PARLIAMENT AND THE COUNCIL (2004a). Regulation (EC) No 1231/2010 extending Regulation (EC) No 883/2004 and Regulation (EC) No 987/2009 to nationals of third countries who are not already covered by these Regulations solely on the ground of their nationality. 24 November 2010 [online]. Available from http://eur-

lex.europa.eu/LexUriServ/LexUriServ.do?uri=OJ:L:2010:344:0001:0003:EN:PDF

HNILICOVÁ H. et al. (2012). Analýza komerčního zdravotního pojištění cizinců [online]. [cit. 18.9.2015], Available from http://www.konsorciumnno.cz/dokumenty/analyza_komercniho_zdravotniho_pojisteni_pro_vybor171012_2012 10180815049.pdf

HNILICOVÁ, H., and DOBIÁŠOVÁ, K. (2011). Migrants' health and access to healthcare in the Czech Republic. Central European Journal of Public Health, 19 (3), 134-138.

KAREŠ, R. (2015). Dialog k reformně: Patří cizinci do veřejného zdravotního pojištění?. Záznam diskusního setkání na téma "Patří cizinci do veřejného zdravotního pojištění?", Sdružení Občan, Available https://www.youtube.com/watch?v=YubkLVA0JK4

KULICH, T. (2014). Začlenění cizinců ze třetích zemí do veřejného zdravotního pojištění v ČR. Final Theses, University of Economics, Prague.

MINISTRY OF HEALTH OF THE CZECH REPUBLIC (2016). Veřejné zdravotní pojištění [online]. [cit. 26.2 .2016$]$ Available from http://www.mzcr.cz/KvalitaABezpeci/obsah/verejne-zdravotni-pojisteni-vcr_3347_29.html

MINISTRY OF HEALTH OF THE CZECH REPUBLIC (2015). Mezinárodní smlouvy [online]. [cit. 18.9 .2015$]$ Available from http://www.mzcr.cz/Cizinci/obsah/mezinarodni-smlouvy_2632_22.html 
MINISTRY OF THE INTERIOR OF THE CZECH REPUBLIC (2013). Zpráva o situaci v oblasti migrace a integrace cizinců na území České republiky v roce 2012 [online]. [cit. 18.9.2015] Available from http://www.mvcr.cz/clanek/zpravy-o-situaci-v-oblastimigrace-a-integrace-cizincu-v-ceske-republice-za-roky-2001-2012.aspx

MINISTRY OF THE INTERIOR OF THE CZECH REPUBLIC (2014). Zpráva o situaci v oblasti migrace a integrace cizinců na území České republiky v roce 2013 [online]. [cit. 18.9.2015] Available from http://www.mvcr.cz/clanek/migracni-a-azylova-politikaceske-republiky-470144.aspx?q=Y2hudW09NA\%3D\%3D

MINISTRY OF LABOUR AND SOCIAL AFFAIRS OF THE CZECH REPUBLIC (2015): Seznam bilaterálních smluv o sociálním zabzpečení [online]. [cit. 18.9.2015] Available from http://www.mpsv.cz/cs/1275

SDRUŽENÍ OBČAN (2015). Diskuse: Patří cizinci do veřejného zdravotního pojištění?. Záznam diskusního setkání na téma "Patří cizinci do veřejného zdravotního pojištění?", $\quad$ Sdružení $\quad$ Občan, Available from https://www.youtube.com/watch?v=YubkLVA0JK4

TEPPEROVÁ, J., and ZÍDKOVÁ, H. (2015a). Potential Revenues from Inclusion of Migrants from the Third Countries into Czech Public Health Insurance System. Proceedings of the 19th International Conference, Current Trends in Public Sector Research, Masaryk University, Brno 2015.

TEPPEROVÁ, J., and ZÍDKOVÁ, H. (2015b). Inclusion of Self-Employed from the Third Countries into the Czech Public Health Insurance System. Proceedings of the 20th International Conference Theoretical and Practical Aspects of Public Finance, University of Economics, Prague, 2015.

TRBOLA, R., and RÁKOCZYOVÁ, M. (eds) (2010). Vybrané aspekty života cizinců v České republice. VPÚS [online], 2010. [cit. 18.9.2015] Available from http://praha.vupsv.cz/Fulltext/vz_319.pdf

VANČUROVÁ, A., MAZOUCH, P., and KLAZAR, S. (2015). Employees' and Selfemployed Persons' Income Distribution in the Czech Republic: Data availability and Initial Results. Proceedings of the 20th International Conference Theoretical and Practical Aspects of Public Finance, University of Economics, Prague, 2015.

VZP. (2015). Češi rozhodněji oproti loňsku odmítají rozšíření veřejného zdravotního pojišsění o další cizince. Tisková zpráva VZP ze dne 27. 11. 2015, Available from https://www.pvzp.cz/cs/tiskova-zprava/cesi-rozhodneji-oproti-lonsku-odmitajirozsireni-verejneho-zdravotniho-pojisteni-o-dalsi-cizince/ 
